\title{
PENGEMBANGAN INSTRUMEN PENILAIAN KINERJA PRAKTIKUM FISIKA KURIKULUM 2013
}

\section{DEVELOPING THE PHYSICS PRACTICUM PERFORMANCE ASSESSMENT INSTRUMENT OF 2013 CURRICULUM}

\author{
Dewi Sartika1), Santih Anggereni'2), Ali Umar Dani' ${ }^{3)}$, Suhardiman ${ }^{4)}$ \\ 1,2,3,4)Fakultas Tarbiyah dan Keguruan Universitas Islam Negeri Alauddin Makassar \\ dewisartika0803@gmail.com ${ }^{1}$, santih.anggereni@uin-alauddin.ac.id ${ }^{2}$, , ali.umardani@gmail.com ${ }^{3}$, \\ suhardiman.hardi@uin-alauddin.ac.id ${ }^{4)}$
}

\begin{abstract}
Abstrak
Tujuan penelitian ini adalah untuk mengetahui prosedur pengembangan, tingkat keefektifan dan kevalidan dari instrumen penilaian kinerja pada mata pelajaran fisika kelas XI IPA 1 di SMA Negeri 14 Gowa. Jenis dari penelitian ini yaitu Research and Development mengacu pada model pengembangan Borg dan Gall. Komponen yang dikembangkan pada penelitian ini adalah perangkat penilaian unjuk kerja praktikum fisika kurikulum 2013. Teknik dalam mengumpulkan data dalam penelitian ini dengan menggunakan angket. Dari hasil penelitian diketahui prosedur pengembangan melalui 7 tahapan sehingga diperoleh instrumen penilaian kinerja pada pelajaran fisika kelas XI IPA yang layak. Berdasarkan hasil analisis data menggunakan scientific approach diperoleh hasil kevalidan pada instrumen penilaian kinerja yang telah direvisi sebanyak 2 kali. Instrumen penilaian kinerja telah memenuhi kategori valid dengan skor rata-rata 0,81 . Uji coba keefektifan pada instrumen memperoleh skor persentase $100 \%$ termasuk dalam kategori efektif. Hal tersebut mengindikasikan bahwa instrumen pada penilaian kinerja yang telah dikembangkan layak digunakan pada kelas XI IPA 1 SMA Negeri 14 Gowa.
\end{abstract}

Kata Kunci: Research and Development, Borg dan Gall, scientific approach

\begin{abstract}
The purpose of this study was to determine the development procedure, the level of effectiveness and validity of the performance assessment instrument in physics class XI IPA 1 at SMA Negeri 14 Gowa. The type of this research is Research and Development which refers to the Borg and Gall development model. The component developed in this study was a 2013 curriculum physics practicum performance assessment tool. The technique of collecting data in this study was using a questionnaire. From the research results, it is known that the development procedure through 7 stages in order to obtain a proper performance assessment instrument in physics class XI IPA. Based on the results of data analysis using the scientific approach, the validity results of the performance assessment instrument were revised 2 times. The performance assessment instrument has met the valid category with an average score of 0.81. Testing the effectiveness of the instrument to obtain a percentage score of $100 \%$ is included in the effective category. This indicates that the instrument for performance assessment that has been developed is suitable for using in class XI IPA 1 SMA Negeri 14 Gowa.
\end{abstract}

Keywords: Research and Development, Borg and Gall, scientific approach 
How to Cite: Sartika, D., Anggereni, S., Dani, A. U., \& Suhardiman. (2020). Pengembangan instrumen penilaian kinerja praktikum fisika kurikulum 2013. Al asma: Journal of Islamic Education, 2(2), 267-273.

\section{PENDAHULUAN}

Tujuan pendidikan nasional adalah mencerdaskan kehidupan bangsa dan mengembangkan kemampuan dan membentuk watak serta peradaban bangsa yang bermartabat agar dapat menjadi manusia beriman dan bertakwa kepada Tuhan Yang Maha Esa, memiliki akhlak mulia, berilmu, sehat, cakap, mandiri, kreatif, serta menjadi warga Negara yang demokratis dan bertanggung jawab (Hermanto, 2020: 54). Kurikulum mengarahkan segala bentuk aktivitas pendidikan demi tercapainya tujuan-tujuan pendidikan.

Kurikulum adalah suatu program dalam pendidikan berisikan berbagai bahan ajar dan pengalaman belajar yang telah diprogramkan, direncanakan dan dirancang secara sistemik atas dasar norma yang berlaku yang dijadikan pedoman dalam proses belajar mengajar bagi tenaga kependidikan dan peserta didik dalam mencapai tujuan dari pendidikan (Zamili 2020: 313). Perubahan kurikulum dari KTSP ke kurikulum 2013, mempersyaratkan menggunakan penilaian secara autentik (authentic assesment). Secara paradigmatik penilaian autentik membutuhkan perwujudan dalam pembelajaran autentik (authentic instruction) dan belajar autentik (authentic learning). Hal tersebut diyakini bahwa penilaian autentik akan lebih mampu dalam memberikan informasi kemampuan peserta didik secara valid dan holistik (Zainuddin, 2015: 136). Guru wajib menggunakan metode yang cocok dengan materi dan mengevaluasi agar dapat mengukur apakah tujuan dari pembelajaran telah tercapai (Majid, 2013: 6). Selain kurikulum, unsur penting lain yang harus dikuasai para guru adalah melakukan penilaian autentik.

Penilaian merupakan proses dalam mendapatkan informasi mengenai prestasi atau kinerja peserta didik. Hasil dari penilaian akan digunakan dalam melakukan evaluasi untuk melihat ketuntasan belajar peserta didik dan efektivitas proses pembelajaran (BSNP, 2007: 5). Menurut Cronbach, penilaian adalah sebuah proses dalam pengumpulan dan penggunaan informasi yang akan dipergunakan sebagai dasar dalam pembuatan keputusan tentang program pendidikan. Keputusan merupakan pilihan diantara berbagai tindakan. Jadi, penilaian menurut Cronbach mempunyai komponen kumpulan informasi dan pembuatan keputusan (Nurgiyantoro, 2010: 10). Peran penilaian kelas untuk meningkatkan siswa belajar dan mengajar guru berutujuan untuk memastikan bahwa siswa mencapai potensinya masing-masing (Earl and Giles 2011). Popham dalam Marhaeni dan Artini (2015: 500) mengungkapkan bahwa harus ada pengembangan instrumen asesmen otentik yang siap untuk digunakan, baik yang dapat menilai performa dalam belajar (proses) atau kualitas dari hasil belajar (produk) secara efektif. Menurut Pantiwati, (2020: 385) authentic assessment adalah proses yang terintegrasi dalam menentukan ciri dan tingkat belajar serta perkembangan belajar peserta didik. Menurut Subagia dan Novita (2017: 419) performance assessment merupakan penilaian yang akan menjadikan peserta didik dalam memperoleh jawaban atau produk yang mendemonstrasikan keterampilan dan pengetahuan mereka.

Berdasarkan hasil observasi awal yang dilakukan oleh peneliti pada hari rabu, 19 Desember 2017 pada Sekolah SMA Negeri 14 Gowa didapatkan bahwa penilaian pada 
praktikum fisika hanya berupa format penilaian secara umum yang akan digunakan untuk seluruh praktikum di SMA Negeri 14 Gowa dan tidak adanya komponen yang harusnya ada pada instrumen penilaian seperti adanya rubrik. Selain dari itu, yang terjadi di SMA Negeri 14 Gowa tidak adanya sebuah alat atau instrumen dalam mengukur hasil kinerja belajar siswa dan masalah ini memerlukan perhatian yang lebih serius dari pihak sekolah, dalam menjawab permasalahan tersebut maka perlu dilakukan pengembangan sebuah instrumen penilaian keterampilan. Pengembangan instrumen tersebut diharapkan dapat memberikan data atau informasi akurat mengenai keterampilan peserta didik. Tujuan peneliti mengembangkan instrumen penilaian kinerja, antara lain untuk mengetahui proses pengembangan instrumen penilaian kinerja, kevalidan pada instrumen penilaian kinerja, dan keefektifan instrumen penilaian pada kinerja mata pelajaran fisika kelas XI IPA 1 SMA Negeri 14 Gowa.

\section{METODE PENELITIAN}

Jenis penelitian yang digunakan dalam penelitian ini adalah penelitian pengembangan (Researh and Development) yaitu pengembangan perangkat penilaian unjuk kerja berbasis praktikum kurikulum 2013. Menurut Sugiyono (2013: 407), metode Research and Development (R\&D) adalah metode penelitian yang digunakan untuk menghasilkan perangkat penilaian unjuk kerja tertentu dan menguji keefektifan perangkat tersebut. Pada penelitian ini terdapat dua subjek, yaitu subjek penelitian dan subjek uji coba. Subjek penelitian dalam pengembangan ini adalah perangkat penilaian kinerja praktikum kurikulum 2013. Komponen yang dikembangkan adalah perangkat penilaian unjuk kerja praktikum Fisika Kurikulum 2013 Kelas XI IPA 1 di SMA Negeri 14 Gowa. Sumber data pada pengembangan ini berasal dari tahap pengumpulan data, tahap validasi desain, tahap uji coba perangkat penilaian kinerja, dan tahap uji pemakaian. Pada tahap pengumpulan data, data diperoleh dari pengisian angket oleh guru mengenai ketersediaan perangkat pembelajaran yang mengacu pada kurikulum 2013 teknik yang diterapkan oleh guru menilai hasil kinerja laboratorium peserta didik, perancangan dan penggunaan penilaian kinerja untuk menilai kinerja siswa yang mengacu pada kurikulum 2013, kesulitan guru dalam membuat dan menggunakan penilaian kinerja, serta kebutuhan untuk pengembangan penilaian unjuk kerja. Pada tahap validasi ahli, data diperoleh dari pengisian angket uji kesesuaian konstruksi, substansi, dan bahasa oleh subjek uji ahli. Pada tahap uji coba perangkat penilaian unjuk kerja dan uji coba pemakaian, data diperoleh dari pengisian angket uji kesesuaian, kebahasan, penulisan, dan penampilan/redaksi oleh guru fisika terhadap perangkat penilaian unjuk kerja hasil pengembangan.

Teknik pengumpulan data dalam penelitian ini dengan menggunakan angket. Pembagian angket dilakukan pada studi lapangan, tahap validasi desain, tahap uji coba perangkat penilaian unjuk kerja, dan tahap uji coba pemakaian. Data hasil analisis kebutuhan yang diperoleh dari kegiatan pengumpulan data digunakan untuk menyusun latar belakang dan mengetahui tingkat keterbutuhan rancangan pengembangan. Data kesesuaian konstruksi, substansi, dan bahasa pada instrumen diperoleh dari ahli materi, ahli desain atau praktisi melalui uji internal perangkat penilaian unjuk kerja. Data mengenai kesesuaian, kebahasan, penulisan dan penampilan/redaksi instrumen diperoleh melalui uji eksternal kepada pengguna secara langsung. Data kesesuaian, kemudahan, dan 
kemanfaatan perangkat tersebut digunakan untuk mengetahui pendapat guru tentang tingkat kelayakan instrumen yang dihasilkan untuk digunakan sebagai instrumen penilaian kinerja.

\section{HASIL DAN PEMBAHASAN}

Tahapan kegiatan pengembangan yang dilakukan beserta dianalisis data yang diperoleh, dapat dideskripsikan sebagai berikut:

1. Analisis penelitian, analisis kebutuhan atau pembuktian konsep

Pada tahap ini peneliti menganalisis produk yang dibutuhkan di SMA Negeri 14 Gowa pada mata pelajaran fisika. Berdasarkan hasil observasi yang dilakukan sebelumnya produk yang dibutuhkan adalah instrumen kinerja. Tahap analisis penelitian dan analisis kebutuhan ini dimaksudkan untuk mengetahui segala sesuatu yang dapat digunakan untuk menunjang pengembangan perangkat penilaian kinerja. Selain itu, untuk mengetahui bagaimana bentuk penilaian kinerja yang ada di sekolah apakah sesuai dengan ketentuan kurikulum 2013, sehingga didapatkan perlu atau tidak pengembangan penilaian otentik pada pembelajaran. Potensi dan masalah yang dikemukakan dalam penelitian harus ditunjukkan dengan data empirik. Dalam hal ini, potensi dan masalah ditunjukkan melalui hasil analisis angket kebutuhan.

2. Perencanaan produk dan desain

Tahap dua dihasilkan rancangan produk dan desain. Tahap perancangan bertujuan untuk merancang produk yang dikembangkan. Tahap ini merupakan tahap penting dalam penelitian karena pada tahap ini akan dikembangkan instrumen penilaian kinerja praktikum fisika kurikulum 2013, dimana peneliti mengumpulkan imformasi, keterangan dan data yang diperoleh selama proses pembuatan desain.

3. Pengembangan perangkat awal

Tahap ketiga yaitu melakukan pengembangan perangkat awal produk yang terdiri atas beberapa bagian yaitu :

a. Menganalisis konten atau materi pembelajaran fisika yang digunakan dalam instrumen penilaian kinerja.

b. Menyusun tugas kinerja yang harus dilakukan peserta didik.

c. Menyusun skenario pembelajaran yang disusun memuat kegiatan pendahuluan, inti, dan penutup.

d. Penyusunan spesifikasi instrumen penilaian kinerja yang dikembangkan, yaitu instrumen penilaian kinerja praktikum fisika kurikulum 2013 pada subtopik Fluida Dinamis yang memuat dua tugas kinerja.

e. Penulisan instrumen penilaian kinerja praktikum fisika kurikulum 2013 diawali dengan penentuan tujuan pengukuran, bentuk dan format instrumen, dan panjang instrumen.

f. Menentukan skala yang digunakan dalam instrumen penilaian kinerja.

g. Menentukan pedoman penskoran.

4. Uji lapangan awal

Tahap keempat yaitu uji lapangan awal dimana rancangan awal yang dimaksudkan adalah produk yang dibuat sebelum tahap coba untuk divalidasi oleh 3 orang ahli praktisi dan ahli pendidikan. Uji ahli dilakukan untuk mengetahui ketidaksesuaian atau kesalahan pada produk yang dibuat baik dari komponen konstruksi, 
komponen tata bahasa, komponen kesesuaian, komponen kemudahan, maupun komponeen kemanfaatan. Data hasil validasi ahli materi dijadikan sebagai acuan untuk melakukan revisi terhadap produk 1 atau produk yang dihasilkan pada tahap ini disebut prototype 1. Prototype 1 ini dilengkapi dengan lembar validasi produk yang diberikan kepada tiga orang validator untuk memberikan penilaian terhadap produk yang telah dirancang apakah layak digunakan untuk tahap uji coba atau tidak.

5. Revisi Perangkat

Tahap kelima yaitu revisi perangkat. Berdasarkan validasi ahli, data yang telah didapatkan digunakan untuk mencari apakah masih ada ketidaksesuaian atau kesalahan pada produk, selanjutnya peneliti melakukan perbaikan atau revisi terhadap produk atau disebut prototype 1 yang dikembangkan sesuai dengan catatan dan saran perbaikan dari validasi ahli. Hasil revisi prototype 1 disebut prototype 2.

6. Uji lapangan besar

Prototype 2 yang diperoleh selanjutnya dilakukan uji lapangan besar. Tahap ini dilakukan dua perlakuan, yaitu prototype 1 dan prototype 2. Prototype 1, yakni uji yang dilakukan guna mengetahui kualitas penilaian kinerja. Uji ini ditunjukan pada guru mata pelajaran fisika yang menagajar di kelas yang hendak diteliti. Tahap ini menggunakan instrumen kesesuaian penilaian kinerja seperti pada tahap validasi ahli. Prototype 2, yakni uji yang dilakukan guna mengetahui efektivitas rubrik penilaian. Tahap ini, guru menggunakan rubrik penilaian yang telah dibuat untuk melakukan penialaian.

Adapun prosedur pelaksanaan uji lapangan besar sebagai berikut.

a. Melakukan uji tahap 1 dengan memberikan instrumen kelayakan penilaian kinerja pada guru.

b. Menganalisis hasil uji lapangan tahap 1 untuk melihat kekurangan dan kelebihan penilaian kinerja pembelajaran fisika yang digunakan.

c. Melakukan revisi produk 2 .

d. Melakukan penilaian kepada siswa menggunakan penilaian kinerja yang telah direvisi. Hal ini, yang melakukan penilaian adalah guru yang mengajar. Ini sudah masuk pada uji lapangan tahap 2 dimana guru menggunakan penilaian kinerja untuk melakukan penilaian.

e. Melakukan uji lapangan tahap 2, uji ini dimaksud untuk mengetahui keefektifan penilaian kinerja untuk penilaian pembelajaran oleh guru.

f. Menganalisis hasil uji lapangan untuk melihat kekurangan dan kelebihan perangkat penilaian knerja pada pembelajaran fisika yang digunakan.

7. Revisi perangkat akhir dan desiminasi

Tahap ketujuh ini menghasilkan sebuah produk yakni rubrik penilaian unjuk kerja yang layak digunakan di SMA Negeri 14 Gowa setelah dilakukan perbaikan berdasarkan masukan dan saran ketiga validator, pembimbing, serta guru hingga instrumen dinyatakan layak untuk digunakan di SMA Negeri 14 Gowa.

Pengembangan instrumen penilaian kinerja praktikum fisika ini berpedoman pada model Borg \& Gall. Kelebihan dari instrumen penilaian kinerja praktikum yang dikembangkan ialah dari segi penilaian saat siswa melaksanakan praktikum, penilaian kinerja tidak lagi hanya berupa format penilaian secara umum tetapi aspek dan indicator yang dinilai jadi lebih spesifik dan terarah. Kekurangannya adalah instrumen penilaian kinerja yang dibuat masih terbatas hanya untuk materi praktikum fluida dinamis dan 
masih belum mencakup keseluruhan materi, penggunaan instrumen ini juga belum dilakukan pada sekolah lain selain dari sekolah yang menjadi objek penelitian. Alasan peneliti adalah karena pertimbangan waktu, tenaga, serta biaya yang terbatas (Borg dan Gall 2003: 7).

Model penelitian yang digunakan penelitian sebelumnya sudah diterapkan juga dalam penelitian Munfaridah, Hardita, dan Kusairi (2016) yaitu (1) Study pendahuluan, (2) Perencanaan, (3) Pengembangan draf produk, (4) Uji coba lapangan awal, (5) Perbaikan (revisi) hasil uji coba, dan (6) Uji coba lapangan keefektifan instrumen penilaian kinerja. Namun produk yang dihasilkan berbeda dengan produk yang dibuat peneliti.

Adapun hasil analisis yang didapatkan dari penelitian ini ialah:

\section{Kevalidan}

Instrumen penilaian kinerja dikatakan valid jika hasil analisis sesuai dengan kriteria yang sudah ditetapkan sebelumnya, dalam artian hasil tes sejajar dengan kriteria (Arikunto, 2009: 69). Tingkat kevalidan diukur menggunakan skala dimana data mentah yang berupa angka harus diubah terlebuh dulu ke dalam bentuk kualitatif (Sugiyono, 2013: 143).

Berdasarkan hasil validasi dari ketiga validator, aspek-aspek instrumen penilaian kinerja yang sudah dikembangkan mendapatkan nilai rerata 0,81. Apabila disesuaikan dengan kategori validitas yang ada, maka hasil validasi berada dalam rentang $v>0,8$ sehingga instrumen penilaian kinerja memenuhi kategori sangat valid. Hasil validasi menunjukkan bahwa aspek penilaian dengan indokator penilaian sudah saling terkait, maka dapat dikatakan bahwa instrumen penilaian kinerja ini bisa digunakan dalam praktikum peserta didik di SMA Negeri 14 Gowa.

\section{Keefektifan}

Keefektifan dapat diukur dengan melihat apakah guru mempertimbangkan bahwa materi mudah dan dapat digunakan oleh guru. Produk tersebut dapat dikatakan efektif jika hasilnya berkategori "Sangat Baik" (Gullicson, 2007). Menurut Nurfathurrahmah dalam Muhammad Mustami dan Dirawan (2015), alat belajar dikatakan efektif apabila memenuhi dua kriteria, yaitu perangkat yang dikembangkan bisa ditentukan dalam (1) penilaian ahli dan (2) bisa diaplikasikan langsung di lapangan.

Dari hasil penilaian angket respons guru didapatkan hasil penilaian analisis yang menunjukkan bahwa hasil nilai reratanya adalah 0,79 , nilai ini berada dalam kategori sangat positif dengan uraian aspek petunjuk dan aspek kecakupan $(0,83)$, serta aspek bahasa $(0,72)$. Angket respons guru diisi oleh tiga guru fisika yang ada di SMA Negeri 14 Gowa. Penilaiannya dilakukan dengan melihat rubrik penilaian kinerja kemudian guru memberikan penilaian ke dalam angket yang sudah diberikan. Hasil analisis angket menunjukkan bahwa hasilnya berada pada kategori sangat positif sehingga produk yang dikembangkan sudah memenuhi kriteria efektif.

\section{SIMPULAN}

Proses pengembangan dari instrumen penilaian kinerja praktikum fisika disesuaikan pada model pengembangan R\&D dengan 7 tahapan yakni dimulai dengan proses menganalisis kebutuhan dimana hasil dari tahapan ini peneliti akan mendapatkan data atau informasi mengenai hal apa saja yang cocok untuk dikembangkan, kemudian merencanakan desain penilaian unjuk kerja yang akan disesuaikan dengan kurikulum 
yang berlaku yakni K13. Selanjutnya, tahap pembuatan instrumen atau yang lebih umum disebut pengembangan perangkat penilaian, tahap uji lapangan awal, revisi awal, uji lapangan skala besar, dan revisi akhir. Pada uji lapangan skala besar diberikan dua perlakuan. Hasilnya diperoleh tingkat kevalidan dari instrumen penilaian kinerja adalah rata-rata 0,81. Nilai tersebut masuk dalam kategori sangat valid, sementara untuk keefektifannya diperoleh persentase $100 \%$, nilai ini termasuk dalam kategori sangat efektif. Hal tersebut mengindikasikan bahwa instrumen pada penilaian kinerja yang telah dikembangkan layak digunakan pada kelas XI IPA 1 SMA Negeri 14 Gowa.

\section{DAFTAR PUSTAKA}

Arikunto, Suharsmini. 2009. Dasar-dasar evaluasi pendidikan. Edisi 2. Jakarta: Bumi Aksara.

Borg and Gall. 2003. Educational research, an introduction. New York: Longman Inc.

BSNP. 2007. Panduan penilaian kelompok mata pelajaran ilmu pengetahuan dan teknologi. Jakarta: Departemen Pendidikan Nasional.

Earl, Kerry and David Giles. 2011. "Assessment in learning." University of Waikato 8(1).

Gullicson, Amy. 2007. "Review of Practical assesment, research and evaluation." United State America: Western Michighan University.

Hermanto, Bambang. 2020. "Perekayasaan sistem pendidikan nasional untuk mencerdaskan kehidupan bangsa." 11(2):52-59.

Majid, Abdul. 2013. Perencanaan pembelajaran mengembangkan standar kompetensi guru. Bandung: PT. Romaja Rosdakarya Offset.

Marhaeni, A. A. I. N. and L. P. Artini. 2015. "Asesmen autentik dan pendidikan bermakna: implementasi kurikulum 2013." Jurnal Pendidikan Indonesia 4(1).

Munfaridah, Nuril, Putri Rizky Hardita, and Sentot Kusairi. 2016. "Pengembangan instrumen performance assesment berbantuan komputer pada materi optik, kalor, dan listrik." Universitas Negeri Malang 5(1).

Mustami, Muhammad Khalifah and Gufran Darma Dirawan. 2015. "Development of worksheet students oriented scientific approach at subject of biology."

Nurgiyantoro. 2010. Penilaian pembelajaran bahasa. Yogyakarta: BPFE-Yogyakarta.

Pantiwati, Yuni. 2020. “Asesmen autentik dalam kegiatan praktik pembelajaran sains."

Subagia, Chandra and DIan Novita. 2017. "Pengembangan instrumen penilaian kinerja (perfomance assessment) untuk menilai keterampilan proses sains peserta didik pada materi reaksi eksoterm dan endoterm kelas XI SMA." Journal of Chemical Education 6(3).

Sugiyono. 2013. Metode penelitian pendidikan pendekatan kuantitatif, kualitatif, dan R\&D. Bandung: Alfabeta.

Zainuddin. 2015. "Implementasi kurikulum 2013 dalam membentuk karakter anak bangsa." Jurnal Islam Kebudayaan 9(1).

Zamili, Uranus. 2020. "Peranan guru dalam pengembangan kurikulum.” 6(3), 11-18. 